\title{
PORT REGIONALIZATION AND LANDLOCKED HINTERLAND: THE CZECH REPUBLIC
}

\section{Rodrigue, J.-P., Kolář, P.}

The expansion of the European Union (EU) and economic growth have propelled the development of intermodal transportation and logistics activities in Central and Eastern Europe (CEE). Yet, the inland location of most CEE economies requires improved connectivity to port terminals on both the Atlantic/Baltic and Mediterranean/Black Sea ranges. The paper provides a broader research perspective on inland logistics platforms focusing on the CEE region, particularly as it concerns the role of the public sector in port hinterland infrastructure development. The paper identifies the current bottlenecks in logistics activity in regard to the whole range of the national transport chains. A dual regionalization process is taking place between the ports of the Northern and Mediterranean ranges and that the Northern Range is more effective at servicing the CEE region, including the Czech Republic, in spite of the proximity advantage of Mediterranean ports.

Keywords: Central and Eastern Europe; freight distribution; intermodal transport; port regionalization; port hinterland; transport policy

JEL classification: L91, L98, M16, M31

\section{Introduction}

This paper focuses on the assessment of the Czech Republic as an intermodal logistics platform within the CEE and the challenges considering intermodal infrastructure developments, operation of transport services, organization of transport chains and their bottlenecks. It seeks to expand the port regionalization thesis by looking at a context where freight distribution is concerning a landlocked location and that two maritime facades are simultaneously competing. The timing and orientation of where the main bottlenecks will be improved in the Czech Republic will strongly influence the scale and orientation of its regionalization.

Since the Czech Republic is a landlocked country, the majority of its international overseas trade depends solely on the efficiency of its rail and road links between nearby European ports, primarily Hamburg, Bremerhaven and Rotterdam in the North Sea Range and Koper on the Adriatic / Mediterranean range. With the European Union (EU) enlargement in 2004, the country has benefited from a surge in exports, which went on par with an increased demand for transport and logistics services. Competition is becoming a matter of quality of the provided transport services ( $\mathrm{Ng}$ and Ducruet, 2014). With attempts to reduce the costs of distribution and with higher transport costs in landlocked countries in general, it is more challenging for manufacturers, distributors, importers and exporters located in the Czech Republic to compete effectively on the global market. As such, the Czech Republic is characterized by a partially landlocked logistics system, implying that even if the country is landlocked, European economic and infrastructure integration substantially mitigates these constraints as compared with fully landlocked countries that do not share a high level of integration with the countries granting access to international maritime trade. The development of efficient, reliable and high capacity corridors towards maritime gateways is thus of strategic importance in this context (Rodrigue et al., 2013). 
The Czech Republic is well positioned to develop a dual port regionalization strategy by catering both to the Northern and Mediterranean ranges. Although this form of port competition (Pallis et al., 2010) and regionalization has been investigated in the Western European context (NEA, 2011), little is known about the structure it will take in the CEE context (Koláŕ, 2013). This uncertainty is further accentuated since the intermodal network is under development and that the structure of this development will influence the regionalization of Northern Range and Mediterranean ports in this part of Europe. National transport policy thus has a window of opportunity to influence port regionalization (Monios and Wilmsmeier, 2012) by providing favorable conditions in terms of legal framework and infrastructure for carriers, operators and their customers.

\section{Regionalization and Layers of Logistics Activity}

The freight transport system of a region can be better understood through four general layers of logistics activity, which include the locational, infrastructure, transport and logistics layers (Rodrigue et al., 2013). The components of these layers have different adaptability levels in facing market changes. From this perspective, it is relevant to look at a comparative framework for logistical platforms, primarily how hinterland access bottlenecks have been addressed in CEE countries that are landlocked or within a broader perspective beyond the CEE region while primarily influenced by port dynamics.

\section{Figure 1 | Transport and economic development layers}

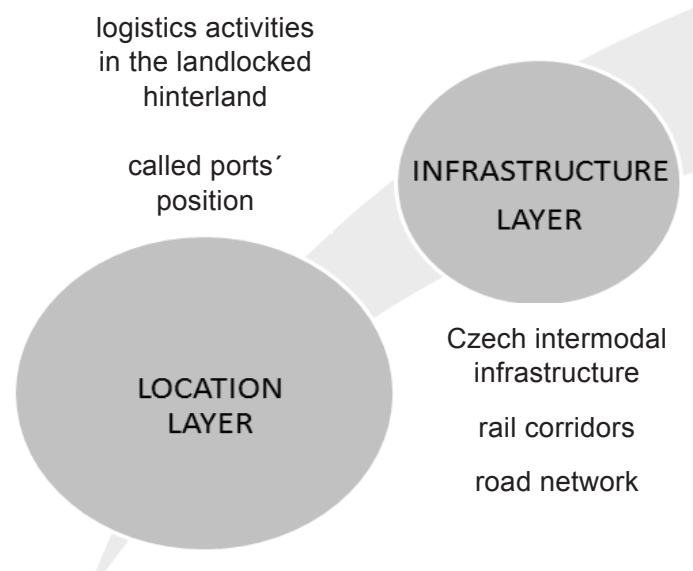

TRANSPORT

LAYER

transport and

supply chain

carriers and

freight

forwardes

relatoons
TRANSPORT

CHAIN

MANAGERIAL

DECISION

MAKING

Source: authors

A systematic perspective of these components and their evolving interactions is usually lacking and is completely absent in case of the Czech Republic.

The existing literature and research covering freight distribution neglects (Woo et al., 2011) or within the CEE usually focuses on specific technical, economic (financial), 
social or political dimensions (TUAS, 2013). This paper advocates that a layer-based approach to logistics activities provides a more comprehensive and multidimensional perspective including logistics activities, inland ports (bringing the massification inland), intermodal infrastructure, road infrastructure and drayage operations, rail corridors and operators, transport and supply chains, relations between carriers and freight forwarders and intermodal transport policy.

Each of these dimensions is part of a specific layer (Notteboom and Rodrigue, 2007) and is characterized with different levels of temporal stability (Figure 1).

The subsequent sections look at these layers in detail. The findings are put into perspective with the regionalization approach in the context of a land locked port hinterland.

\section{Location Layer - Dimensions in the Czech Republic}

\subsection{Logistics Activities}

Port location positively affects the accessibility of the Czech Republic to the international trade routes if complemented with efficient infrastructure links and transport services between the port and its hinterland (OECD and ITF, 2009). In other words, the location and proximity of the Northern Sea Range ports shapes the Czech Republic's logistics activities. In spite of the fact that the Czech Republic is an export oriented economy with a consistent foreign trade surplus, imports represent $60 \%$ of the total containerized cargo being handled. Transportation in maritime (ISO) containers represents $96.6 \%$ of all intermodal transport (in tons) including the maritime leg. In 2012, 520, 000 Twenty-Foot Equivalent Unit (TEU) were handled by the Czech Republic with $74.2 \%$ of containers being full. The remaining $25.8 \%$ represents empty containers repositioned to yards and depots mostly in Germany and Poland (MDCR, 2013).

For the Czech Republic's overseas containerized trade, the transportation of containers (regardless of the mode) is handled by a limited set of gateway ports (Hamburg, Bremerhaven, Koper and Rotterdam). Two different port clusters for imports and exports can be identified. First, there are the most important European ports within the North Sea Range. Second, several of the North Adriatic ports also have to be considered. For the Czech Republic, only four of the above mentioned ports have a significant market share in terms of containerized cargo.

The port of Hamburg dominates with a 60 percent share (300,000 TEU), followed by Bremerhaven (19\%), Koper (15\%), Rotterdam (3\%) and Piraeus (2\%) (SSL CR, 2016). A recent study estimated the port-to-region accessibility in relation to maritime liner service costs underline that the Northern Range ports have a cost advantage in relation to Adriatic ports for the Asia trade (NEA, 2011).

\subsection{Inland Ports}

The development of inland ports is a fundamental aspect for a more effective integration of hinterlands to port ranges, particularly when a country is partially landlocked. The maintenance and expansion projects for making the Elbe River navigable year-long is incomplete and can thus cannot be used as an inland waterway for container shipping (Hafen Hamburg, 2013). 


\section{Infrastructure Layer: Its Dimensions and Bottlenecks in the Czech Republic}

For the Czech Republic, the infrastructure layer includes intermodal container terminals and depots located within the country or those located abroad (mostly in Germany and used for the repositioning of empty containers) and the rail corridors and road network used for the export and import of containerized cargo from the gateway ports.

\subsection{Intermodal Infrastructure}

The European logistics market heavily depends on road transport (Steer Davies Gleave, 2009). The quality and capacity of linkages that include connectivity between roads and motorways, road and rail container terminals and to container ports used for exports and imports are the core factors defining the position of the Czech Republic within CEE intermodal transport chains. As such, the Czech Republic has a modal profile than differs from its European counterparts (European Commission, 2013).

Main container rail-road terminals in term of their stacking capacity container are owned and operated by private companies. The key Prague Uhrineves terminal and Ceska Trebova terminal are operated by METRANS (capacity 15,000 TEUs) and are the biggest inland rail container terminals in the CEE with annual lifts of about 300,000 TEUs. A significant share of transshipment for the Czech containerized cargo trade also takes place at Dunajska Streda terminal in Slovakia,which is linked to the port of Koper in Slovenia.

In terms of the effective intermodal transport utilization, discrepancies are observed. The Dunajska Streda container terminal has the same capacity as the terminal operated by METRANS in Prague, including the same equipment pool (such as terminal cranes and reach stackers). However, it transships only $60 \%$ of the TEU turnover of Prague's. This is due to lower rail capacity for consolidated container trains from Adriatic ports such as Koper despite the rail linkage Koper - Budapest (with high capacity rail diversion to Dunajska Streda terminal) being one of the Trans-European Transport Networks (TEN-T) rail axes but with insufficient public support and co-funding (in Slovenia). The location of the main intermodal rail-road terminals does not reflect the needs and location of the national logistic activities and commercial interests, which results in high levels of road haulage. In addition, there is limited liberalization of the rail sector, implying a less competitive rail market (Mazáč et al., 2010).

A key challenge of this dimension within the infrastructure level of logistics activity resides in the availability of intermodal equipment (containers and chassis) by the shipping lines in the local market to satisfy the requirements of exporters. Most shipping lines have conventionally a high percentage of empty containers in backhaul trades to the Far East. Since there is an excess of container imports in the Czech Republic, most containers (special equipment such as reefer containers or tank containers) are repositioned via Czech or Germany located container depots for German exports or being shipped empty back to the Far East where a high demand for empty containers persists to fulfil exports.

\subsection{Road infrastructure}

The road network of the Czech Republic has to handle high volumes of transit transport between Germany and Balkan (South-East Europe) countries. The highway links have been under enlargement and reconstruction with completion spanning through 2013 
- 2020 and co-financed by EU funds. The current construction projects have already started causing delays for both national and transit traffic. The most salient issue is thus the insufficient pace of development of the motorway network. The network is unable to cope with the increasing number of transit movements that took place after the EU enlargement of 2004. The most critical case concerns the missing part of the D8 motorway between Prague and Dresden (Germany). At the same time, the infrastructure is deteriorating due to insufficient maintenance funding, with the exception of the motorway network co-financed by TEN-T projects. These projects are strictly linked to EU funds and their 6 year-budget periods regardless of changes in national transport policy objectives and their financing. Since there is more supranational project control and auditing involved, these projects are usually less delayed compared to those solely financed by national or regional public funds.

\subsection{Rail Corridors}

The Czech Republic has the highest rail network density $(124 \mathrm{~km} / 1,000 \mathrm{~km} 2)$ in the European Union (Eurostat, 2015). The total track length is $9,505 \mathrm{~km}$, with $2,926 \mathrm{~km}$ being electrified and nearly all the network meeting the standard European $1435 \mathrm{~mm}$ gauge (RIA, 2013). Most rail infrastructure is state owned and managed by the Rail Infrastructure Administration (RIA), which also sets the rail use pricing policy for the rail operators. Most of the rail corridors are used by operators running consolidated container trains between the main intermodal terminals and the main container ports (Hamburg, Bremerhaven, Rotterdam and Koper). There are four rail corridors being part of TEN-T rail corridors. The key rail operator in the intermodal market is METRANS. With the country being part of the pan European rail network with corridors transporting nearly 1 million TEUs per year that are partly transshipped by main intermodal terminals, it is essential to mitigate organizational, legal and technical bottlenecks in rail infrastructure. One of the key obstacles includes limited rail interoperability in combined and intermodal transport chains without required connections to logistics and industrial centers by rail sidetrack (TASW, 2011). Public support for revitalization of used rail sidetracks is missing despite the availability of EU funding. Generally, the terminal or logistics facilities operators favor its realization without time-consuming bureaucratic processes related to the EU funding system in the Czech Republic. Besides, public-private partnership (PPP) infrastructure projects are not even proposed since PPP cooperation faces many process and organizational issues in the area of road infrastructure.

In regard to the National Transport Policy of the Czech Republic for $2012-2020$ (MDCR, 2012), the rail infrastructure is favored to road haulage both by financial public support and its strategic position. On the other hand, private sector involvement is still lacking since the Government has not included the rail transport stakeholders in the Policy proposal and its implementation. The situation may change since rail cargo carriers and operators have recently established a trade group (Association of Rail Cargo Operators; ZESNAD) to promote their interests within the national policy.

\section{Transport Layer: Its Dimensions and Bottlenecks in the Czech Republic}

The transport layer of logistics activity includes operations by transport and supply chain actors (e.g. shipping lines, freight forwarders, rail operators and road carriers). Each is characterized by different market power and ongoing change in their relations, which is determined by their level of cooperation and competition. 


\subsection{Transport and Supply Chain}

One of the most important relations concerns carriers and freight forwarders that act as customers under carrier haulage contracts and as competitors in the case of the merchant haulage contracts (Panayides et al., 2011), arranging inland transportation and related services between the port and inland beneficiary cargo owners.

There are 18 shipping lines with their branch offices or agents' offices in the Czech Republic (SSL CR, 2016). Nevertheless, a substantial share of containerized cargo is managed by parent offices located in Germany or Austria. The Czech container market is quite specific in terms of high level of carrier haulage by the shipping lines with relatively low ratio of merchant haulage having freight forwarders as key party for inland transportation.

Generally, the decision making power of the Czech branches is rather limited. Proposals related to strategic sales decision making need to be confirmed by the European branch office in Austria (Vienna), Germany (Hamburg) or the United Kingdom (London). The freight forwarders market is mostly dominated by German headquartered companies. Besides, it is very difficult to draw a line between the markets positioning of freight operators (Poláček, 2015) since some of the freight forwarders such as Kuhne \& Nagel start to play an important role as non-vessel operating common carrier (NVOCC) (Šrámková and Niko, 2014).

The road haulage carriers market is fragmented, which is common in the industry. Due to the high level of competition and low margins, the mid-sized and small-sized freight forwarders are active in contracting carriers with only several trucks in operation to provide both international and regional haulage (Schramm, 2012). Market fragmentation in the road transport sector is also associated with a wide range of service quality in part due to the lack of training level for truck drivers.

\subsection{Carriers and Freight Forwarders}

The relation between the carriers and the freight forwarders concerns market power between these players and beneficial cargo owners. The key final customers for the freight forwarders and container transport shipping lines in the Czech Republic include: automotive and aircraft industry, electronic assembly, retailing goods or, leather manufacturing and clothing semi-products.

\section{Conclusion}

The emergence of a dual regionalization process in the Czech Republic for the port clusters of the Northern Sea range (primarily Hamburg) and the East-Mediterranean Adriatic (Koper and Rijeka) is unfolding. This dualism involves two maritime ranges with their respective regionalization strategies that have different scale and scope and thus outcomes.

On the long run, the TEU turnover share of North Sea ports is likely to increase since they provide more favorable conditions for their customers (shipping lines, distributers and 3PLs). This scenario will be enhanced with cooperation between public policy makers implementing the national transport policy and market players such as carriers and terminal operators. NS range ports are better linked to their CEE hinterland in terms of rail and 
road infrastructure. North Adriatic ports can be called by vessels with a maximum capacity of 10,000 TEUs, which is less competitive compared to the economies of scale of 12,000 - 20,000 TEUs ships handled by main North Sea ports. This is further underlined by the insufficient funding for rail infrastructure development in Adriatic ports. Despite shorter transit time between the Far East compared to Northern Sea Range, namely Hamburg or Rotterdam, ports such as Koper or Rijeka will continue to serve as complementary ports to shipments to the Czech Republic and the CEE in general. At this point, there is limited evidence available that could change this imbalanced relationship, underlining that once effective regionalization strategies have been implemented, they are excessively difficult to reverse. In spite of locational advantages, the infrastructure layer has a deep influence on freight flows and logistics.

Table 1 summarizes the logistics layers, their respective dimensions and the key issues the Czech Republic faces.

A multidimensional perspective for intermodal transport in the Czech Republic and the identification of the relevant bottlenecks underline that no effective long-term national transport policy has been developed for container transport. Unless this shortcoming is mitigated, the Czech Republic will continue to have its trade flows mostly influenced by the strategies of external actors such as shipping lines and freight forwarders.

Table 1 | Logistics layers, their dimensions and related bottlenecks for the Czech Republic

\begin{tabular}{|l|l|l|}
\hline Logistics Layer & \multicolumn{1}{|c|}{ Dimension } & \multicolumn{1}{c|}{ Bottleneck } \\
\hline Location & $\begin{array}{l}\text { Logistics activities } \\
\text { Ports of calls } \\
\text { Inland ports }\end{array}$ & $\begin{array}{l}\text { Landlocked. } \\
\text { Limited accessibility to Adriatic ports. }\end{array}$ \\
\hline Infrastructure & $\begin{array}{l}\text { Intermodal infrastructure } \\
\text { Road infrastructure } \\
\text { Rail corridors }\end{array}$ & $\begin{array}{l}\text { Availability of equipment. Insufficient } \\
\text { pace of development. } \\
\text { No connections to logistics and } \\
\text { industrial centers. } \\
\text { Limited dialogue between public and } \\
\text { private actors. Limited public support } \\
\text { to the rail transport sector. }\end{array}$ \\
\hline Transport & $\begin{array}{l}\text { Transport and supply chain } \\
\text { carriers and freight } \\
\text { forwarders }\end{array}$ & $\begin{array}{l}\text { High level of service quality } \\
\text { fluctuations. } \\
\text { Limited customer loyalty. }\end{array}$ \\
\hline $\begin{array}{l}\text { Transport chain and } \\
\text { managerial decisions }\end{array}$ & Transport policy & $\begin{array}{l}\text { No policy specifically developed } \\
\text { for intermodal and container transport. }\end{array}$ \\
\hline
\end{tabular}

Source: authors

\section{References}

Czech Statistical Office (2013). External trade 2012. Retrieved March 12, 2016, from http:// www.czso.cz/eng/edicniplan.nsf/aktual/ep-6.

De Langen, P. W. (2007). Port competition and selection in contestable hinterlands: the case of Austria. European Journal of Transport and Infrastructure Research, 7(1), 1-14. 
European Commission (2013). EU transport in figures 2012. Retrieved April 11, 2016, from http://ec.europa.eu/transport/facts-fundings/statistics/doc/2012/pocketbook2012.pdf.

Eurostat (2015). Inland transport infrastructure at regional level. Retrieved February 4, 2016, from http://ec.europa.eu/eurostat/statistics-explained/index.php/ Inland_transport_infrastructure_at_regional_level.

Hafen Hamburg (2015). The Czech Republic's traffic links with the port of Hamburg. Retrieved May 12, 2015, from https://www.hafen-hamburg.de/en/content/ czech-republic\%E2\%80\%99s-traffic-links-port-hamburg.

Kolář, P. (2013). Container shipping market dimensions and customer orientation in the Czech Republic. Central European Business Review, 2(4), 50-53.

Mazáč, P., Cempírek, V., Nachtigall, P., Široký, J., \& Šourek, D. (2010). Situation on intermodal market in FLAVIA countries. Perner's Contacts, 4(5), 151-158.

MDCR (2012). Ministry of Transport of the Czech Republic. Retrieved March 2, 2015 from http:// www.mdcr.cz/NR/rdonlyres/DB292074-62B4-4B09-9D43-9697A1A86FB0/0/B1300298_ MINISTERSTVO_DOPRAVY_2014_2020_ENG05.pdf.

MDCR (2013). Combined Transport Department Head interview. Ministry of Transport of the Czech Republic. Retrieved May 12, 2013.

Monios, J. \& Wilmsmeier, G. (2012). Giving a direction to port regionalization. Transportation Research Part A: Policy and Practice, 46(10), 1551-1561.

NEA (2011). The Balance of container traffic amongst European ports. Retrieved July, 12 2015, from http://www.panteia.eu/Projects/ /media/9\%20PanteiaEU/files/The\%20Balance\%20 of\%20Containertraffic\%20amongst\%20European\%20Ports.ashx.

Ng, A. K. Y., \& Ducruet, C. (2014). The changing tides of port geography (1950-2012). Progress in Human Geography, 38(6), 785-823.

Notteboom, T., \& Rodrigue, J.-P. (2007). Re-assessing port-hinterland relationships in the context of global supply chains. In Wang, J., Oliver, D., Notteboom, T. \& B. Slack (Eds.), Inserting port-cities in global supply chains. London: Ashgate.

OECD \&ITF. (2009). Port Competition and Hinterland Connections. Paris: OECD Publishing.

Pallis, A. A., Vitsounis, T. K. \& De Langen, P. W. (2010). Port economics, policy and management: Review of an emerging research field. Transport Reviews, 30(1), 115-161.

Panayides, P. M., Lambertides, N. \& Savva, C. S. (2011). The relative efficiency of shipping companies. Transportation Research Part E: Logistics and Transportation Review, 47(5), 681-694.

Poláček, B. (2015). Resolution of Disputes in the International River and Maritime Transport in Arbitration. In Bělohlávek \& A. J., Rozehnalová, N. (Eds.), Czech Yearbook of International Law - Volume VI, New York: Juris Publishing.

PWC \& Pantheia (2013). Final report: Impact assessment on: Measures to enhance the efficiency and quality of port services in the EU. Retrieved February 12, 2016, from http://ec.europa. eu/transport/modes/maritime/studies/doc/2013-07-ia-port-services.pdf.

RIA (2013). Basic characteristics of SZDC railway network. Railway Infrastructure Administration. Retrieved October 26, 2015 from http://www.szdc.cz/en/o-nas/ zeleznice-cr/zeleznicni-sit-v-cr.html.

Rodrigue, J-P., Camtois, C., \& Slack, B. (2013). The Geography of Transport Systems Third Edition. New York: Routledge. 
Schramm, H. J. (2012). Freight Forwarder's Intermediary Role in Multimodal Transport Chains: A Social Network Approach. Berlin, Heidelberg: Physica-Verlag.

SSL CR (2016). Carriers presentation and panel discussion. Association of Forwarding and Logistics of the Czech Republic. Retrieved May 13, 2016.

Steer Davies Gleave (2009). Evaluation of the Common Transport Policy (CTP) of the EU from 2000 to 2008 and analysis of the evaluation and structure of the European transport sector in the context of the long-term development of CTP. Retrieved September 29, 2015 from http://ec.europa.eu/transport/themes/strategies/studies/doc/future_of_ transport/20090908_common_transport_policy_final_report.pdf.

Šrámková, E. \& Niko, E. (2014). Integrované globální řešení pro sledování kontejnerů. Perner's Contacts, 9(3), 196-207.

TUAS (2013). FLAVIA - Freight and Logistics Advancement in Central/ South-East Europe Validation of trade and transport processes, Implementation and Application. Technical University of Applied Sciences Wildau. Retrieved January 11, 2015 from http://www. th-wildau.de/en/forschungsgruppen/verkehrslogistik/projekte/projekteaktuell/flavia. html.

Woo, S. H., Pettit, S., Kwak, D. W. \& Beresford, A. K. (2011). Seaport research: A structured literature review on methodological issues since the 1980s. Transportation Research Part A: Policy and Practice, 45(7), 667-685.

\section{Authors}

\section{Dr. Jean-Paul Rodrigue}

Professor

Department of Global Studies and Geography, Hofstra University

Hempstead, NY 11549, USA

Jean-paul.Rodrigue@hofstra.edu

\section{Ing. Petr Kolář, Ph.D.}

\section{Assistant Professor}

Department of Logistics, Faculty of Business Administration, University of Economics, Prague nám. W. Churchilla 4, 13067, Prague 3, Czech Republic

petr.kolar@vse.cz

The related research project is co-financed by the University of Economics, Prague Grant Agency, project no. VSE IP305026. 